\title{
Amaltheys: A fluorescence-based analyzer to assess cheese milk denatured whey proteins
}

\author{
Pierre Lacotte, ${ }^{*}$ Franck Gomez, ${ }^{*}$ Floriane Bardeau, ${ }^{*}$ Sabine Muller, ${ }^{*}$ Abdelhaq Acharid, ${ }^{*}$ Xavier Quervel, $\dagger$ \\ Philippe Trossat, $\dagger$ and Inès Birlouez-Aragon ${ }^{* 1}$ \\ *Spectralys Innovation, 93230 Romainville, France \\ †ACTALIA Cecalait, 39802 Poligny, France
}

\begin{abstract}
The cheese industry faces many challenges to optimize cheese yield and quality. A very precise standardization of the cheese milk is needed, which is achieved by a fine control of the process and milk composition. Thorough analysis of protein composition is important to determine the amount of protein that will be retained in the curd or lost in the whey. The fluorescence-based Amaltheys analyzer (Spectralys Innovation, Romainville, France) was developed to assess $\mathrm{pH}$ 4.6-soluble heat-sensitive whey proteins ( $\left.\mathrm{sWP}^{*}\right)$ in 5 min. These proteins are those that can be denatured upon heat-treatment and further retained in the curd after coagulation. Monitoring of sWP* in milk and subsequent adaptation of the process is a reliable solution to achieve stable cheese yield and quality. Performance of the method was evaluated by an accredited laboratory on a 0 to $7 \mathrm{~g} / \mathrm{L}$ range. Accuracy compared with the reference Kjeldahl method is also provided with a standard error of $0.25 \mathrm{~g} / \mathrm{L}$. Finally, a 4-mo industrial trial in a cheese plant is described, where Amaltheys was used as a process analytical technology to monitor sWP* content in ingredients and final cheese milk. Calibration models over quality parameters of final cheese were also built from near-infrared and fluorescence spectroscopic data. The Amaltheys analyzer was found to be a rapid, compact, and accurate device to help implementation of standardization procedures in the dairy industry.
\end{abstract}

Key words: fluorescence spectroscopy, soluble whey protein, denatured whey protein, cheese yield, process analytical technology

Received February 2, 2015.

Accepted May 8, 2015.

${ }^{1}$ Corresponding author: ines.birlouez@spectralys.fr

\section{INTRODUCTION}

The milk industry is one of the most automated food processing industries. For example, the different steps of cheese manufacturing process are monitored continuously to standardize cheese milk protein content, using at-line and inline near-infrared spectrometry (NIR) analyses (O'Callaghan, 1998). Milk proteins are mainly separated into 2 families - caseins and whey proteinsthe latter may become denatured upon heat-treatment and form complex aggregates with caseins. Caseins and denatured whey proteins (DWP) are, in turn, retained in curd upon acidification or rennet addition, whereas soluble (i.e., not denatured) whey proteins are lost in cheese whey after coagulation and drainage. To gain yield, many cheese plants heat the milk before rennet coagulation to increase the content of proteins in the curd.

However, at present, quality problems due to variability in heat-denatured whey protein content cannot be anticipated, as NIR only assesses total proteins (caseins + whey proteins) in real time, and not the protein fraction that will be retained in curd (caseins + DWP). The main solution in case of observed underquality of the product or coagulation problems consists of stopping the process with a loss of productivity. Anticipating milk whey protein variability and adapting pasteurization temperature is the main challenge in this respect, but such an approach requires real-time analyses of milk samples whey proteins at each step of the process to standardize the product more accurately. For example, monitoring soluble whey proteins in the cheese milk before and after pasteurization enables assessment of DWP formed during the heat-treatment. In case of fluctuations that could affect curd cutting time and subsequent yield and quality, corrections can be carried out by modifying either the cheese milk recipe or the process parameters (Jovanovic et al., 2005; Abd El-Gawal and Ahmed, 2011). 
More generally, characterization of milk whey proteins is of major interest for the dairy industry, as these proteins have a very high nutritional value (Ha and Zemel, 2003) and various technological and biological functionalities (de Wit, 1998; Foegeding et al., 2002). Thus, they are commonly used in whey ingredients, such as whey protein concentrate or whey protein isolate, and in many food products (infant formulas, yogurts, cappuccino, biscuits, and so on). Whey proteins comprise $\beta$-LG ( 60\%), $\alpha$-LA $(\sim 30 \%)$, BSA $(\sim 8 \%)$, lactoferrin, and various immunoglobulins in minor concentrations. All these proteins can be denatured upon heating, although with different kinetic rates (Dannenberg and Kessler, 1988). As such, native (i.e., nondenatured) and DWP coexist in most dairy products.

The reference method to analyze proteins in milk is the Kjeldahl method (Kjeldahl, 1883), based on mineralization of the sample followed by quantification of total nitrogen. Nitrogen content is then converted into protein content using a mean conversion coefficient of 6.38 for milk proteins. Noncasein nitrogen (NCN) determination requires prior extraction, achieved by decreasing milk $\mathrm{pH}$ from 6.8 to 4.6 , thus inducing precipitation of caseins and DWP. However, the remaining supernatant does not contain only soluble heat-sensitive whey proteins, but also other nitrogen fractions that cannot be denatured, even upon extended heating. The NPN fraction is composed of ammoniac, urea, free AA, and small peptides, and the proteose-peptone (PP) fraction is a complex mixture of casein hydrolysis peptides produced through the action of plasmin as well as endogen glycoproteins (Karamoko et al., 2013). This latter fraction may be determined as a whole using the Rowland procedure (Rowland, 1938).

Various fast methods have been developed as alternatives to the Kjeldahl method. The Dumas method considerably accelerates nitrogen quantification and has been proposed for soluble whey proteins analysis (Chiaccherini et al., 2003). However, the detection limit is high (0.06 $\mathrm{g}$ of protein/100 $\mathrm{g}$ of solid product) and a 3 -step sample preparation is needed. Furthermore, the Dumas method is not adapted to NPN analysis because of the incompatibility of the system with the trichloroacetic buffer used to precipitate milk proteins. The 1-anilino-8-naphtalene sulfonate technique provides a relative but quick estimation of DWP by measuring surface hydrophobicity of the proteins (Bonomi et al., 1988; Saulnier et al., 1991). For 15 yr, very few NIR-based prediction models have been developed for assessment of specific protein fractions in milk; some calibrations over casein content have been successful on cow raw milks (Laporte and Paquin, 1999; Jankovska and Sustova, 2003), goat raw milks (Drackova et al.,
2008), or reconstituted casein solutions (Marinoni et al., 2013). Overall, they do not seem to provide reliable assessment in milk samples of different compositions (Pouliot et al., 1997) and thermally processed. However, to our knowledge, some NIR calibrations do exist over (caseins + DWP) content in some dairy companies, although maintenance of the model requires numerous Kjeldahl analyses per day.

In the current paper, we present the first rapid atline technique measuring directly the $\mathrm{pH}$ 4.6-soluble whey proteins $\left(\mathbf{s W P}^{*}\right)$ concentration of milk at different steps of the process. The measurement is achieved thanks to a patented fluorometric method (BirlouezAragon, 1997) and implemented in the compact Amaltheys analyzer (Spectralys Innovation, Romainville, France). The goal of our paper was first to evaluate this new method's performance with sWP*, measuring linearity, stability, and accuracy compared with the reference Kjeldahl method. Second, we demonstrated the technique's potential as process analytical technology (PAT) tool; finally, use of Amaltheys in a Danish cheese plant to monitor cheese yield and quality is presented.

\section{MATERIALS AND METHODS}

\section{Amaltheys Analyses}

Principle of the Amaltheys Analyzer. Amaltheys is a compact and portable right-angle fluorometer designed with 2 excitation light-emitting diodes at 280 and $340 \mathrm{~nm}$, a spectrometer with high collection efficiency and a rugged optical design, and a low noise and enhanced UV sensitivity linear charge-coupled device. The emission output ranged from 200 to $800 \mathrm{~nm}$ and was preprocessed by embedded electronics and analog filters. Additional processing provided direct sWP* values on the built-in graphical user interface, and raw spectra could be downloaded to an external PC for further analysis.

Measurement Principle. The general principle of the method is to measure the natural fluorescence of peptidic Trp to assess the sample protein concentration. Sample preparation aims at obtaining a UVtransparent (optical density <0.2) solution to allow direct quantification of Trp concentration using the Beer-Lambert law. This is achieved through precipitation of caseins and DWP using a buffer at $\mathrm{pH}$ 4.6. Fluorescence of Trp is given by automatic measurement at 280 and $340 \mathrm{~nm}$ (excitation and emission wavelengths), Trp concentration being proportional to the protein concentration. Quantification becomes possible thanks to calibration using a standard of known concentration 
in the same buffer. The fluorescence measurement itself takes around $20 \mathrm{~s}$, so that complete analysis of a sample is carried out in about $5 \mathrm{~min}$.

Sample Preparation. A precision electronic pipette (Pipetman M 100-1,000 $\mu \mathrm{L}$, Gilson, Middleton, WI) was used to dispense $1 \mathrm{~mL}$ of milk in a $50-\mathrm{mL}$ tube. Then, $50 \mathrm{~mL}$ of a $\mathrm{pH} 4.55$ sodium acetate buffer (Spectralys Innovation) was added using an automatic volume dispenser (Fisher Scientific, Pittsburgh, PA). Precipitation of caseins and DWP occurred within 3 min, after which the supernatant was filtered on a 0.45 $\mu \mathrm{m}$ nylon filter in a 4-face optical acrylic cuvette.

$s \boldsymbol{W} \boldsymbol{P}^{*}$. As described previously and illustrated in Figure 1, sWP$^{*}$ mainly consist in $\alpha-\mathrm{LA}, \beta-\mathrm{LG}$, BSA, lactoferrin, and immunoglobulins. All these proteins can be heat-denatured and do possess Trp residues. They are known as heat-sensitive whey proteins, and are measured with Amaltheys when nondenatured. However, the other $\mathrm{pH}$ 4.6-soluble fractions (namely $\mathrm{PP}$ and NPN) are not fluorescent because they have no Trp residues; as such, they are not measured by this technique, which only assesses the soluble part of heat-sensitive whey proteins.

Calibration with an $s$ WP ${ }^{*}$ External Standard. The external standard consists of $1.0 \mathrm{mg}$ of lyophilized whey protein isolate in $\mathrm{pH} 4.6$ buffer (Spectralys In- novation) and was produced by the accredited laboratory Cécalait (Poligny, France). A master standard was then prepared using a solution of one part $\alpha$-LA (Sigma-Aldrich, St. Louis, MO) and two parts $\beta$-LG (Sigma-Aldrich), whose concentration was assessed by the reference NCN-NPN Kjeldahl method (Cécalait). This standard accounts for pure sWP* solution and is used to determine sWP* content of lyophilized standards with the Amaltheys method after rehydration in $10 \mathrm{~mL}$ of demineralized water. External standards were checked to be stable for 6 mo when stored at $-18^{\circ} \mathrm{C}$ (data not shown).

\section{Evaluation of Amaltheys Technique and Comparison to Kjeldahl}

Our study was carried out by the independent accredited French laboratory Cécalait in agreement with the ISO8196-3 norm (ISO, 2011). Samples were composed of 29 raw cow milks (mean sWP* $=5.25$ $\mathrm{g} / \mathrm{L}, \mathrm{SD}=0.63 \mathrm{~g} / \mathrm{L}$ ) and 41 heat-treated milks (mean $\mathrm{sWP}^{*}=2.89 \mathrm{~g} / \mathrm{L}, \mathrm{SD}=1.53 \mathrm{~g} / \mathrm{L}$ ). Raw milk samples were purchased from Candia (Sodiaal Group, Paris, France). Heat-treated milk samples were obtained from various French milk industries to encompass the greatest variability in sWP* content; samples were issued

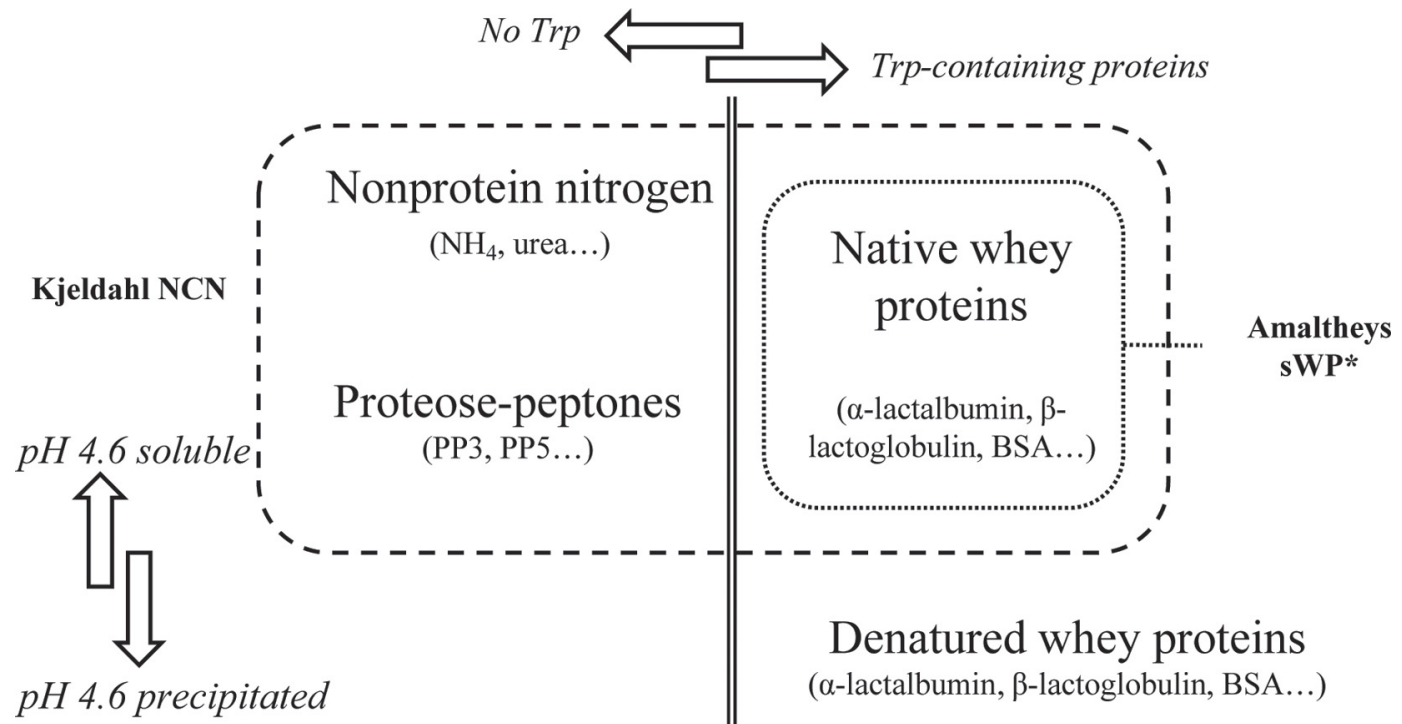

Caseins

$\left(\alpha_{\mathrm{S} 1}, \beta, \kappa \ldots\right)$

Figure 1. Nitrogen fractions of milk, as measured by Kjeldahl method [noncasein nitrogen (NCN), NPN] and Amaltheys (Spectralys Innovation, Romainville, France) method [pH 4.6-soluble heat-sensitive whey proteins (sWP*)]. 
from different steps of milk processing (standardized or pasteurized, UHT-treated, and so on) in hard and soft cheesemaking processes. Samples were added for bronopol, stored at $4^{\circ} \mathrm{C}$, and analyzed within a week from production day.

Normalized methods based on Kjeldahl determination of protein nitrogen were used to check the accuracy of the alternative Amaltheys method. The various specific protein fractions were analyzed: total nitrogen (Kjeldahl method, ISO8968-1; ISO, 2014), NCN (Kjeldahl method, ISO17997; ISO, 2004), NPN (Kjeldahl method, ISO8968-4; ISO, 2001), and PP (Rowland, 1938).

Statistical analysis of the regressions was carried out using Microsoft Excel (Redmond, WA), for determination of slope, intercept, coefficient of determination, and standard error of the estimate. The confidence interval for slope and intercept was set at $95 \%$.

\section{Assessment of Amaltheys in an Industrial Cheese Plant}

Amaltheys measurements were carried out on 54 different batches treated within 7 production days in a European fresh cheese plant. The process is described below and illustrated in Figure 2. First, fresh raw milk was skimmed to obtain skim milk. Skim milk was then mixed together with dairy ingredient 1 and ingredient 2 to obtain the standardized milk (total protein: mean $=44.63 \mathrm{~g} / \mathrm{L}, \mathrm{SD}=0.60 \mathrm{~g} / \mathrm{L}$; and fat: mean $=4.26 \mathrm{~g} / \mathrm{L}$, $\mathrm{SD}=0.46 \mathrm{~g} / \mathrm{L})$. Standardized milk was pasteurized for $15 \mathrm{~s}$ at either temperature (T1; 39 batches) or temperature 2 (T2; 15 batches), with $\mathrm{T} 2=\mathrm{T} 1+5^{\circ} \mathrm{C}$, to obtain

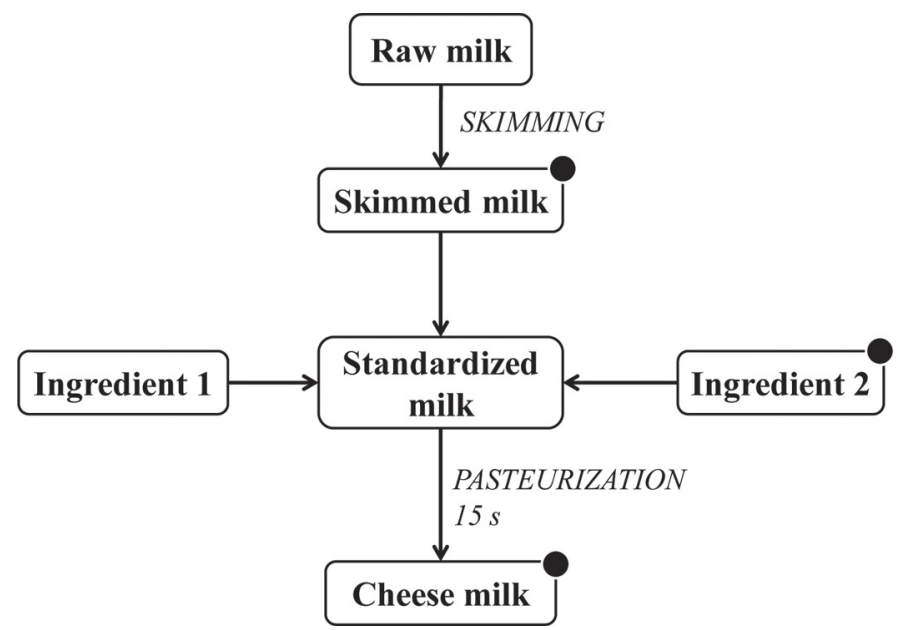

Figure 2. Simplified process of cheese milk production in a fresh soft cheese industrial plant. Black dots indicate the sampling points for further analyses. the cheese milk. Finally, cheese and whey were obtained after coagulation of cheese milk using rennet.

The sWP* measurements were carried out on skim milk and ingredient 2, as well as on final cheese milk using Amaltheys. Total protein content in cheese milk and ingredients was measured by NIR spectroscopy (Milkoscan, Foss, Hillerød, Denmark) using appropriate calibration packs (Foss). For each processed batch (mean batch volume $=11,300 \mathrm{~L}$ ), weight amounts of whey (in $\mathrm{kg} / 100 \mathrm{~L}$ of cheese milk) and final cheese (in $\mathrm{kg} / 100 \mathrm{~L}$ of cheese milk), as well as protein content in final cheese (in $\mathrm{kg} / \mathrm{kg}$ of final cheese), were assessed by standard methods.

Multilinear regressions and statistical analyses were carried out using Matlab (The MathWorks Inc., Natick, MA). Only the significant variables $(P<0.05)$ were used for building of each calibration model. Root-mean square error of calibration (RMSEC) was calculated and divided by the mean value of the distribution to give a relative standard error. For each model, predicted values were plotted against observed values, and regression parameters $\left(\mathrm{R}^{2}\right.$, slope, and intercept) were determined with a confidence interval of $95 \%$ using Microsoft Excel.

\section{RESULTS AND DISCUSSION}

\section{Evaluation of sWP* in Milk Samples Using Amaltheys}

Repeatability, Stability, and Linearity. Repeatability error was measured to be stable at $0.100 \mathrm{~g} / \mathrm{L}$, regardless the concentration in raw or heat-treated milk samples. It was also similar to that of Kjeldahl NCN corrected for NPN content $\left(\mathrm{S}_{\mathrm{R}}=0.092 \mathrm{~g} / \mathrm{L}\right.$, where $\mathbf{S}_{\mathrm{R}}$ is reproducibility $\mathrm{SD}$ ). For evaluation of stability, measurements were carried out on the same 3 samples each 15 min for $4 \mathrm{~h}$; reproducibility standard deviations of the 16 measurements remained $<5 \%$, demonstrating the stability of the measurement (Table 1). Linearity of the instrument was checked by analyzing a range of 11 model samples obtained by mixing raw milk $\left(\mathrm{sWP}^{*}=\right.$ $5.60 \mathrm{~g} / \mathrm{L})$ and UHT-treated milk $\left(\mathrm{sWP}^{*}=0.80 \mathrm{~g} / \mathrm{L}\right)$; the quantification followed a linear curve on the 0 to

Table 1. Stability of Amaltheys (Spectralys Innovation, Romainville, France) $\mathrm{pH}$ 4.6-soluble heat-sensitive whey proteins (sWP*) measurements ${ }^{1}$

\begin{tabular}{lccc}
\hline Product & Raw milk & Pasteurized milk & UHT milk \\
\hline $\mathrm{S}_{\mathrm{R}}(\mathrm{g} / \mathrm{L})$ & 0.16 & 0.18 & 0.05 \\
Mean sWP $^{*}(\mathrm{~g} / \mathrm{L})$ & 5.56 & 5.20 & 1.08 \\
$\mathrm{~S}_{\mathrm{R}}(\%)$ & 2.9 & 3.4 & 5.0 \\
\hline
\end{tabular}

${ }^{1}$ Sixteen samples of each product were analyzed each 15 min for $4 \mathrm{~h}$. Average sWP* $^{*}$ content $(\mathrm{g} / \mathrm{L})$ are indicated, and reproducibility SD $\left(\mathrm{S}_{\mathrm{R}}\right)$ were calculated. 
6672

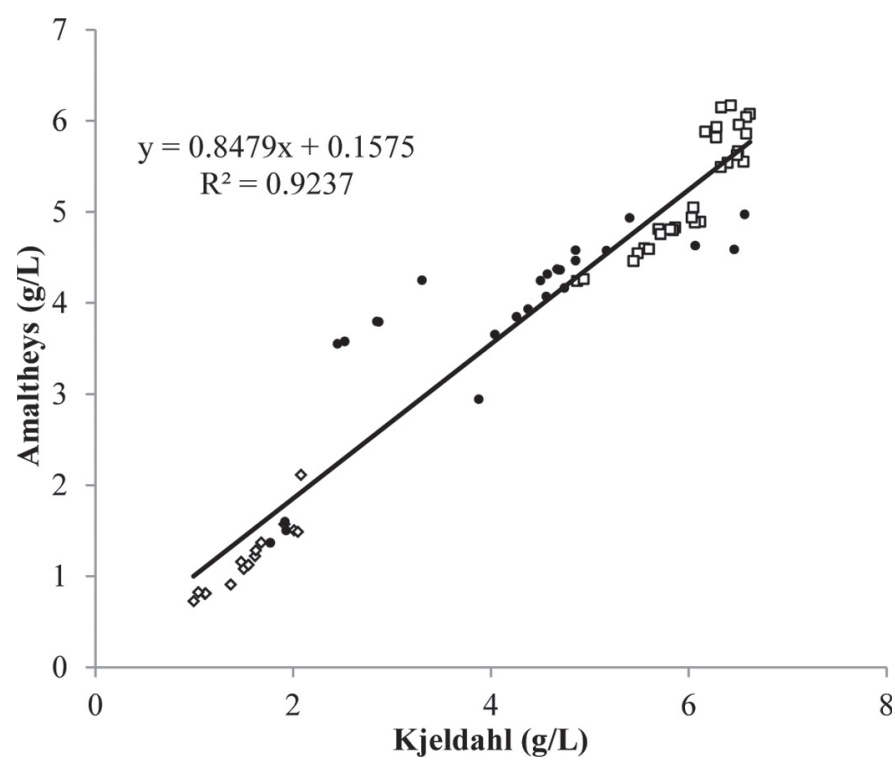

Figure 3. Linear regression between $\mathrm{pH}$ 4.6-soluble heat-sensitive whey proteins $\left(\mathrm{sWP}^{*}\right)$ as measured by Amaltheys (Spectralys Innovation, Romainville, France) method and Kjeldahl method (noncasein $\mathrm{N}-\mathrm{NPN}$ ). White squares $(\square)$ = raw milks; black dots ( $=$ pasteurized or standardized milks or both; white diamonds $(\diamond)=$ UHT-treated milks.

$6 \mathrm{~g} / \mathrm{L}$ range $(\mathrm{a}=1, \mathrm{~b}=0 ; P<0.05)$, compatible with soluble whey protein variability in heat-treated milk samples (Table 2). The quantification limit was calculated to be $11 \mathrm{mg} / \mathrm{L}$ (Kjeldahl $=100 \mathrm{mg} / \mathrm{L}$ ) based on the limit under which the reproducibility error significantly increases above $S_{R}$.

Accuracy Compared with Kjeldahl. Accuracy of sWP* measurement with Amaltheys was evaluated by comparison with the normalized Kjeldahl method. As NPN does not contain Trp, Amaltheys results were first compared with NCN and NPN values. The regression between the 2 techniques (Figure 3 ) was associated with a high correlation coefficient $\left(\mathrm{R}^{2}=0.92\right)$ but also with a bias in the slope $(\mathrm{a}=0.85, \mathrm{SD}=0.03)$. The intercept was not significantly different from $0(P<$ $0.05)$, but the standard error of prediction was also high $\left(\mathrm{S}_{\mathrm{y}, \mathrm{x}}=0.47 \mathrm{~g} / \mathrm{L}\right.$, where $\mathrm{S}_{\mathrm{y}, \mathrm{x}}$ is standard error of prediction). Though the regression was relatively poor, in the 2 to $4 \mathrm{~g} / \mathrm{L}$ range, more heat-treated samples in this zone are required to strengthen the statistics.

The differences observed between Amaltheys and Kjeldahl measurements are because Kjeldahl NCN and NPN measures not only sWP*, but also the PP fraction. As widely described, the major components of PP fraction, namely PP3, PP5, PP8F, and PP8S, have been sequenced and do not contain any Trp residue (Andrews, 1979; Pedersen et al., 2012). This fraction is also well known for its resistance to heat-denaturation (Pâquet, 1989). Measurement of sWP $^{*}$ is of major interest for cheese industries compared with Kjeldahl NCN and NPN, because it specifically assesses the only whey proteins that can be heat-denatured and retained in the curd. To better evaluate the accuracy of Amaltheys sWP* determination, we proposed to correct the Kjeldahl NCN and NPN value by the PP value, measured according to Rowland's procedure $\left(\mathbf{P P}_{\mathbf{R}}\right)$. The new regression between these 2 data sets is presented in Figure 4. It is characterized by an increased coefficient of determination $\left(\mathrm{R}^{2}=0.96\right)$ and a sharp decrease of the prediction error $\left(\mathrm{S}_{\mathrm{y}, \mathrm{x}}=0.32 \mathrm{~g} / \mathrm{L}\right)$. Still, the slope bias $(\mathrm{a}=1.19, \mathrm{SD}=0.03)$ and the intercept remain significantly different from $0(P<0.05)$.

It appears that this modification somehow overcorrected Kjeldahl NCN and NPN values. By taking a closer look at Rowland's method, it is debatable whether a 15-min heating of milk is insufficient to denature all the Trp-containing proteins (Dannenberg and Kessler, 1988). In particular, some heat-sensitive whey proteins have been seen in Rowland's supernatants (Shida et al., 1994; Fox and McSweeney, 2003), including $\alpha$-LA or glycosylated $\beta$-LG. For example, alternative protocols for PP extraction have been proposed with higher heattreatment (Pâquet et al., 1988). As such, a residual fluorescence was still observed in Rowland's supernatants (data not shown). To correct for this bias, Rowland supernatants were measured on Amaltheys and the residual fluorescence quantified using pure $\alpha$-LA solution as standard $($ mean $=0.9 \mathrm{~g} / \mathrm{L})$. Indeed, according to Dannenberg and Kessler (1988), heat-treatment at $90^{\circ} \mathrm{C}$ for $15 \mathrm{~min}$ is responsible for $>99 \%$ denaturation of $\beta$-LG, but only $90 \%$ of $\alpha$-LA. Thus, we hypothesized

Table 2. Linearity of Amaltheys (Spectralys Innovation, Romainville, France) pH 4.6-soluble heat-sensitive whey proteins $\left(\mathrm{sWP}^{*}\right)$ measurements; for each sample are given the calculated theoretical value $(\mathrm{g} / \mathrm{L})$ and the measured value $(\mathrm{g} / \mathrm{L})$

\begin{tabular}{|c|c|c|c|c|c|c|c|c|c|c|c|}
\hline \multirow[b]{2}{*}{ Item } & \multicolumn{11}{|c|}{ Experimental sample number } \\
\hline & 1 & 2 & 3 & 4 & 5 & 6 & 7 & 8 & 9 & 10 & 11 \\
\hline Measured sWP* & 5.61 & 4.97 & 4.81 & 4.27 & 3.85 & 3.22 & 2.82 & 2.36 & 1.92 & 1.33 & 0.80 \\
\hline Calculated sWP* & 5.61 & 5.14 & 4.65 & 4.20 & 3.72 & 3.18 & 2.76 & 2.27 & 1.84 & 1.29 & 0.80 \\
\hline
\end{tabular}




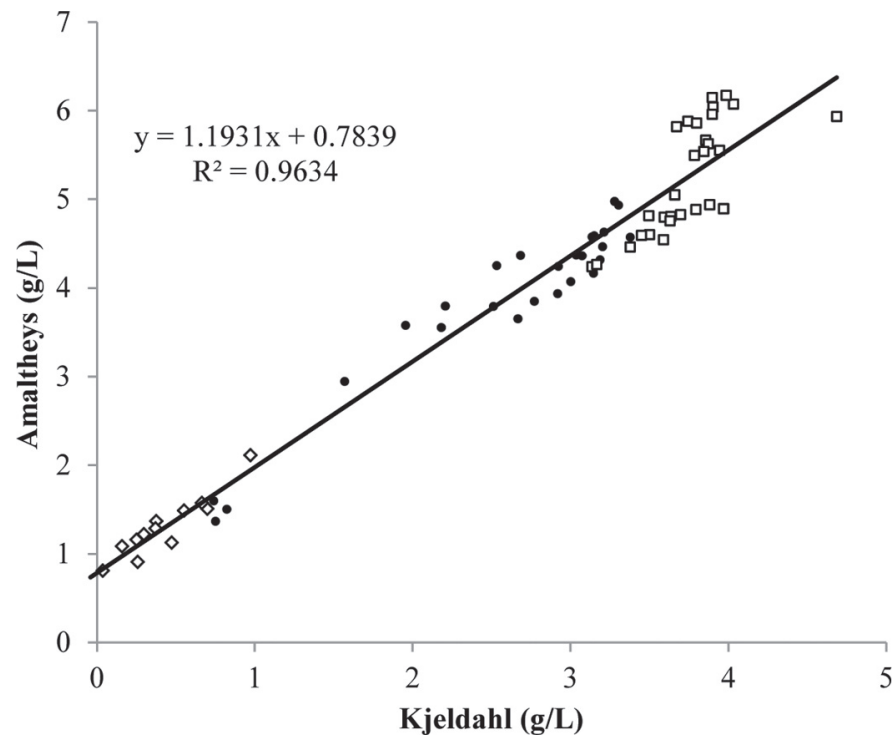

Figure 4. Linear regression between $\mathrm{pH}$ 4.6-soluble heat-sensitive whey proteins $\left(\mathrm{sWP}^{*}\right)$ as measured by Amaltheys (Spectralys Innovation, Romainville, France) method and Kjeldahl noncasein N, after correction by Rowland's proteose-peptone fraction $\left(\mathrm{PP}_{\mathrm{R}}\right)$. White squares $(\square)=$ raw milks; black dots $(\bullet)=$ pasteurized or standardized milks or both; white diamonds $(\diamond)=$ UHT-treated milks.

that the main component of the remaining fluorescent fraction was $\alpha$-LA. The resulting concentrations were then subtracted from $\mathrm{PP}_{\mathrm{R}}$ values. The new regression between Amaltheys and the corrected Kjeldahl is presented in Figure 5. Correction by residual fluorescence of $\mathrm{PP}_{\mathrm{R}}$ fraction significantly increased the quality of the regression against Kjeldahl parameters, as coefficient of determination increased to 0.98 . We observed that a residual slope bias subsists $(\mathrm{a}=1.04, \mathrm{SD}=0.02)$, and the intercept is still significantly different from $0(P<$ $0.05)$. Finally, prediction error was decreased down to $\mathrm{S}_{\mathrm{y}, \mathrm{x}}=0.24 \mathrm{~g} / \mathrm{L}$, a very low level compatible with the sum of analytical errors.

The remaining intercept $(\mathrm{b}=0.47, \mathrm{SD}=0.07)$ and the slight slope bias suggest that Kjeldahl values are still over-corrected. Furthermore, we investigated $\mathrm{PP}_{\mathrm{R}}$ values and corrections by residual fluorescence, given in Table 3. Literature data are rather scarce and heterogeneous, as various methods of PP isolation and quantification have been used. Previously reported PP values include $2.28 \mathrm{~g} / \mathrm{L}$ by electrophoresis in fresh milk (Andrews, 1979), between 0.50 and $3 \mathrm{~g} / \mathrm{L}$ for raw whole milks (Pâquet, 1989), and 0.11 to $3.37 \mathrm{~g} / \mathrm{L}$ by HPLC in raw milks (Buccioni et al., 2013). Our values seem to be in agreement with those, although it is impossible to conclude precisely on the validity of our correction. Thus, we suggest that the remaining slope bias and intercept could be due to our choice of $\alpha$-LA as standard for $\mathrm{PP}_{\mathrm{R}}$ Trp-containing proteins quantification.

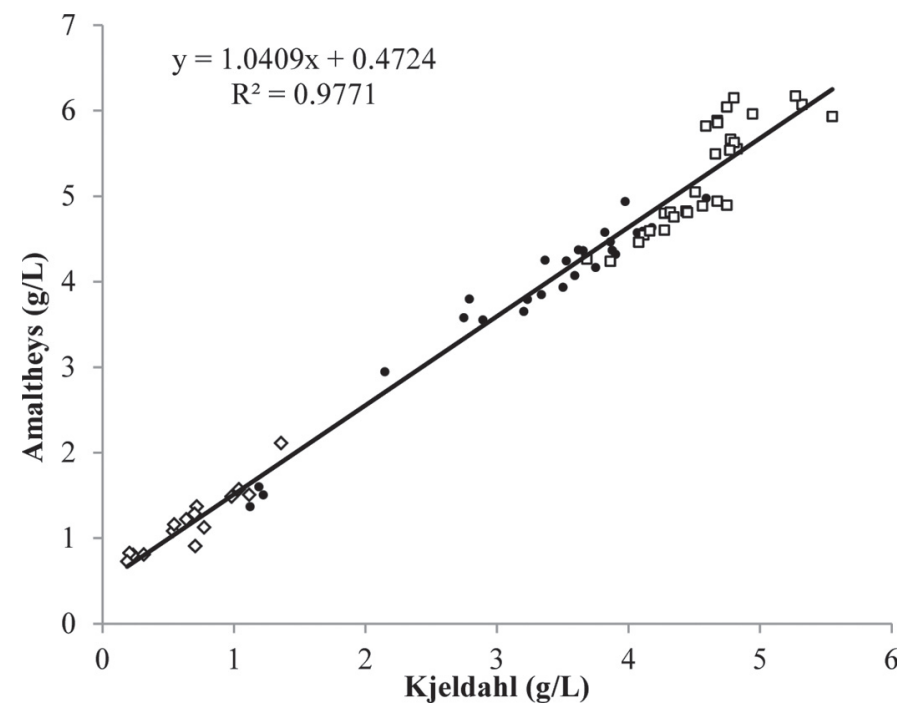

Figure 5. Linear regression between $\mathrm{pH}$ 4.6-soluble heat-sensitive whey proteins $\left(\mathrm{sWP}^{*}\right)$ as measured by Amaltheys (Spectralys Innovation, Romainville, France) method and Kjeldahl noncasein N, after correction by Rowland's proteose-peptone $\left(\mathrm{PP}_{\mathrm{R}}\right)$ and $\mathrm{PP}_{\mathrm{R}}$ residual fluorescence. White squares $(\square)=$ raw milks; black dots $(\bullet)$ $=$ pasteurized or standardized milks or both; white diamonds $(\diamond)=$ UHT-treated milks.

\section{Influence of $s W P^{*}$ Fluctuations on Cheese Yield and Quality}

To study the potential of Amaltheys as a PAT, a study was carried out for 4 mo (November 2013-February 2014) in a European cheese plant producing fresh soft cheese.

Characterization of Ingredients. The sWP* analyses were carried out on the 3 ingredients of cheese milk, including skim milk, for 15 production days $(\sim 3$ wk). The 15 batches were measured to assess protein variability; as shown in Figure 6, we demonstrated that the amount of sWP $^{*}$ in ingredients is fluctuating, up to $25 \%$ variation in some cases. These variations have

Table 3. Protease-peptone (PP) values according to Rowland's procedure $\left(\mathrm{PP}_{\mathrm{R}}, \mathrm{g} / \mathrm{L}\right)$ and corrected values for residual fluorescence $(\mathrm{g} / \mathrm{L})$

\begin{tabular}{lccc}
\hline & $\begin{array}{c}\text { No. of } \\
\text { samples }\end{array}$ & $\mathrm{PP}_{\mathrm{R}}$ & Corrected $\mathrm{PP}_{\mathrm{R}}$ \\
\hline Raw milk & 29 & & \\
$\quad$ Average & & 2.30 & 1.45 \\
$\quad$ SD & 26 & 0.31 & 0.24 \\
Pasteurized and standardized & & & \\
milks & & 1.56 & 0.87 \\
$\quad$ Average & & 0.78 & 0.69 \\
$\quad$ SD & 15 & & \\
$\quad$ UHT-treated milks & & 1.21 & 0.87 \\
$\quad$ Average & & 0.13 & 0.11 \\
$\quad$ SD & & &
\end{tabular}




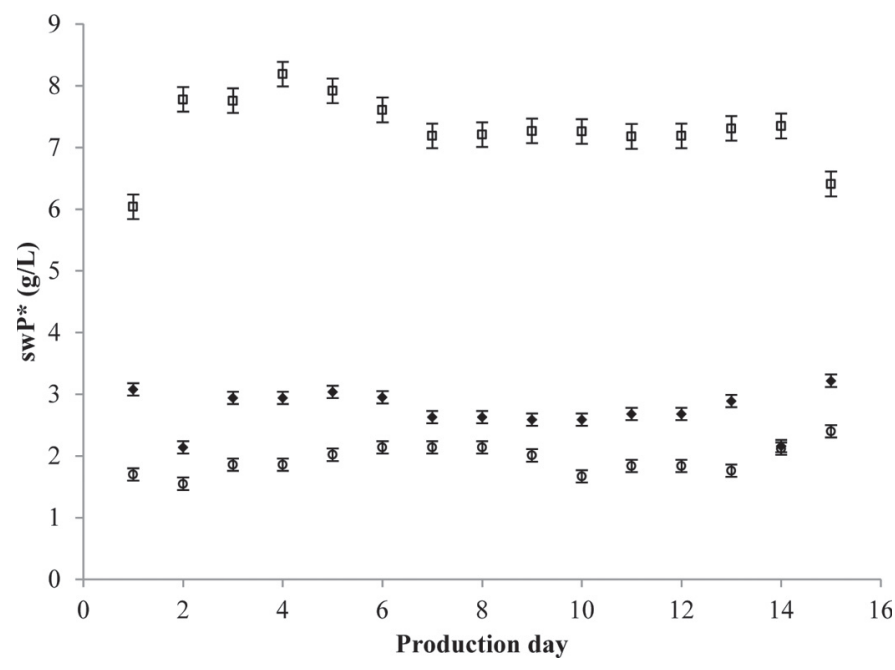

Figure 6. Fluctuations of Amaltheys (Spectralys Innovation, Romainville, France) pH 4.6-soluble heat-sensitive whey proteins $\left(\mathrm{sWP}^{*}\right)$ content $(\mathrm{g} / \mathrm{L})$ over 15 production days in ingredients used for cheese milk. White squares $(\square)=$ skim milk; black diamonds $(\bullet)$ $=$ ingredient 1 ; white circles $(O)=$ ingredient 2 . Error bars represent repeatability standard deviation of Amaltheys analysis on 2 measurements.

a direct effect on the total amount of protein in the final cheese, and can be used as a key parameter to standardize product quality.

Effect of Process Temperature on Cheese Milk Protein Composition. Amaltheys was also used to compare the cheese milk protein composition depending on the pasteurization temperature applied to the cheese milk (T1 and T2, Figure 7). On each cheese milk sample, sWP* concentration was determined. Denatured whey proteins formed during the pasteurization step could then be assessed by subtracting sWP* content in cheese milk to sWP* content in standardized milk. As expected, the most heat-treated milks contained fewer sWP* $($ mean $=5.90 \pm 0.36$ vs. $6.57 \pm 0.21$ $\mathrm{g} / \mathrm{L}$ ) and more DWP (mean $=0.65 \pm 0.18$ vs. $0.06 \pm$ $0.14 \mathrm{~g} / \mathrm{L}$ ) than the least heat-treated ones. Therefore, we demonstrated that Amaltheys is a sensitive tool to qualify the effect of heat-treatment processes on whey protein denaturation, as it distinguishes clearly cheese milk samples processed at 2 close temperatures.

Prediction of Cheese Yield and Quality Based on Amaltheys Measurements on Cheese Milk. Amaltheys sWP* measurements may also be used in combination with other analytical results to build calibration models over yield and quality parameters of final cheese. Multilinear regressions were built using Amaltheys data coupled with total protein content of the various ingredients, as measured by NIR spectroscopy. Variables used for calibration models are described in Table 4. Not all the variables were used, depending on the models. Calibration models were established over protein content in final cheese (expressed in kilograms per kilogram of cheese), whey amount released after coagulation (expressed in kilograms per $100 \mathrm{~L}$ of cheese milk), and cheese yield (expressed in kilograms of final cheese per $100 \mathrm{~L}$ of cheese milk).

A first calibration model (Figure 8) was built over the weight amount of proteins in final cheese with performances of $\mathrm{n}=54$ and RMSEC $=0.06 \%$. Multilinear regression was achieved with only 3 variables (V1, V2, and V3) and 50 degrees of freedom. Coef-
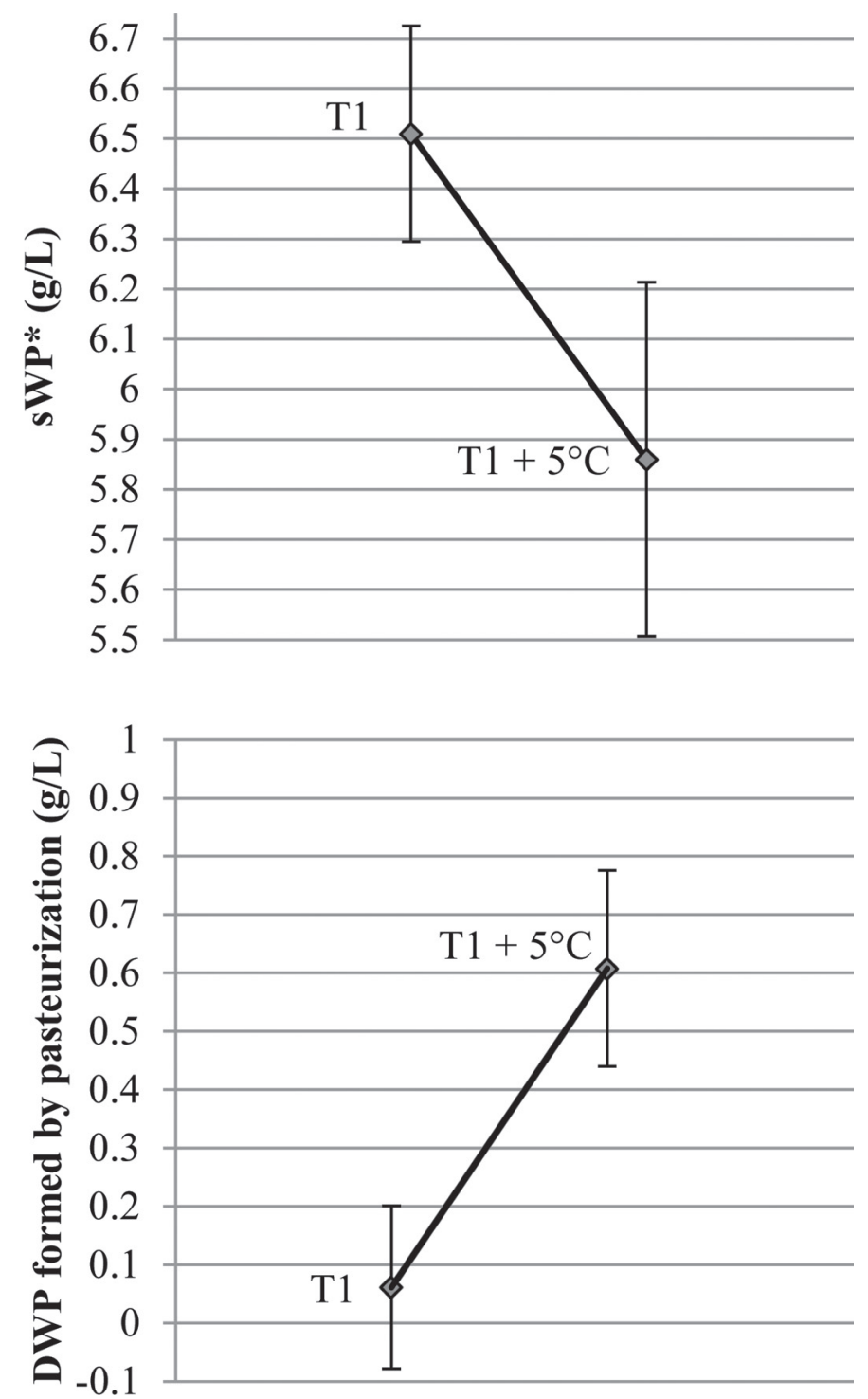

Figure 7. Effect of pasteurization temperature on cheese milk $\mathrm{pH}$ 4.6-soluble heat-sensitive whey proteins ( $\mathrm{sWP}^{*}$ ) and denatured whey proteins (DWP) content $(\mathrm{g} / \mathrm{L})$ using Amaltheys analyzer (Spectralys Innovation, Romainville, France). Error bars represent intraclass variance, ANOVA. 
Table 4. Variables (V) used for building of regression models; for each product are indicated batch volume (L), near infrared-protein (g/L) and Amaltheys (Spectralys Innovation, Romainville, France) pH 4.6-soluble heat-sensitive whey proteins $\left(\mathrm{sWP}^{*} ; \mathrm{g} / \mathrm{L}\right)$

\begin{tabular}{lccccccccc}
\hline Product & V1 & V2 & V3 & V4 & V5 & V6 & V7 & V8 & V9 \\
\hline Cheese milk & sWP* & Batch & Protein & & & & & & \\
Skim milk & & volume & & sWP* & $\begin{array}{c}\text { Batch } \\
\text { volume }\end{array}$ & Protein & & & \\
Ingredient 2 & & & & & & & sWP* & $\begin{array}{c}\text { Batch } \\
\text { volume }\end{array}$ & Protein \\
\hline
\end{tabular}

ficient of determination was 0.999 and the intercept was not significant $(P>0.05)$. Such good statistics can be explained by the fact that Amaltheys sWP* were the proteins found in cheese whey after coagulation, along with minerals and lactose, whereas all the other proteins were retained on the curd. The proportion of whey proteins coagulating with casein strongly depends on cheese milk composition and prior heat treatment.

A second model was built over the weight amount of whey released after curd formation. Only 2 variables (V1 and V2) were used to explain $98 \%$ of the variability with 53 degrees of freedom. The regression is displayed in Figure 9 and exhibited similar performances $(\mathrm{n}=$ 56, RMSEC $=0.13 \%$ ). Coefficient of determination was 0.98 and, again, the intercept was not significant $(P>$ 0.05 ). Finally, a third model (Figure 10) consisted in a calibration over final cheese weight (kilograms per $100 \mathrm{~L}$ of cheese milk). As this major quality parameter depends not only on the protein content, but also on the fat and water retained in the curd, all the variables were necessary (V1 to V9) with 32 degrees of freedom. Performances were lower than for the other models, although satisfying $(\mathrm{n}=42, \mathrm{RMSEC}=1.45 \%)$, and 14 outliers $(25 \%)$ had to be removed.

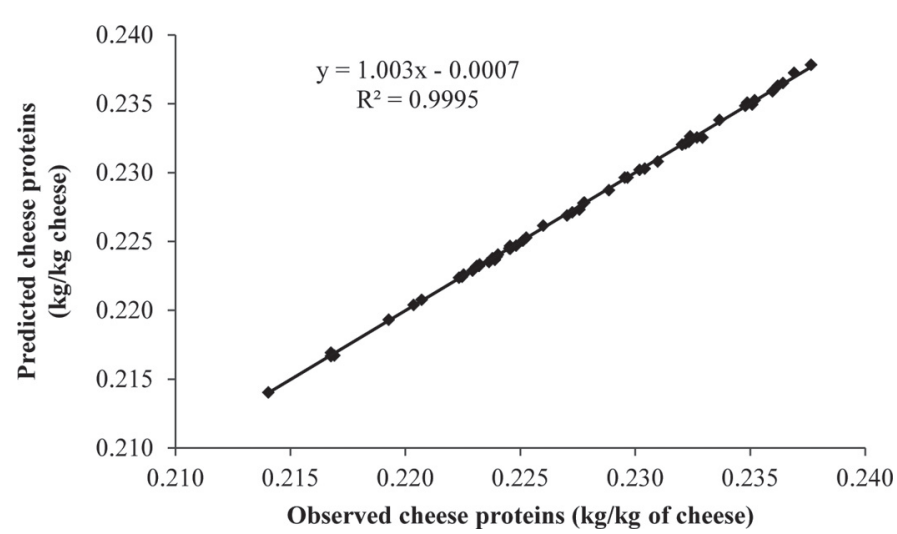

Figure 8. Calibration model established with Amaltheys (Spectralys Innovation, Romainville, France) measurements over cheese proteins $(\mathrm{kg} / \mathrm{kg}$ of cheese).
In summary, DWP content of cheese milk constitutes an uncontrolled factor of variability that directly affects final cheese quality and yield (Guyomarc'h, 2006). Such variability is due to variations in sWP* content in the raw milk and ingredients used for preparing the milk cheese. This fraction is directly measured by Amaltheys, and the measurement can then be coupled with other analytical data to provide a quick and accurate assessment of main quality parameters in final cheese. It must be emphasized at this point that the case study was carried out on a fresh cheese process. However, as shown previously, the method can be applied on samples from other process types (e.g., soft and hard cheeses), thus allowing a large utilization in cheese manufacturing plants. For a given process, Amaltheys can then be used as a rapid PAT tool to correct the process to reach the desired cheese quality and control cheese yield.

\section{CONCLUSIONS}

This work aimed at presenting Amaltheys, the first fluorescence analyzer for soluble whey protein assessment in $5 \mathrm{~min}$ in the dairy industry. The analyzer al-

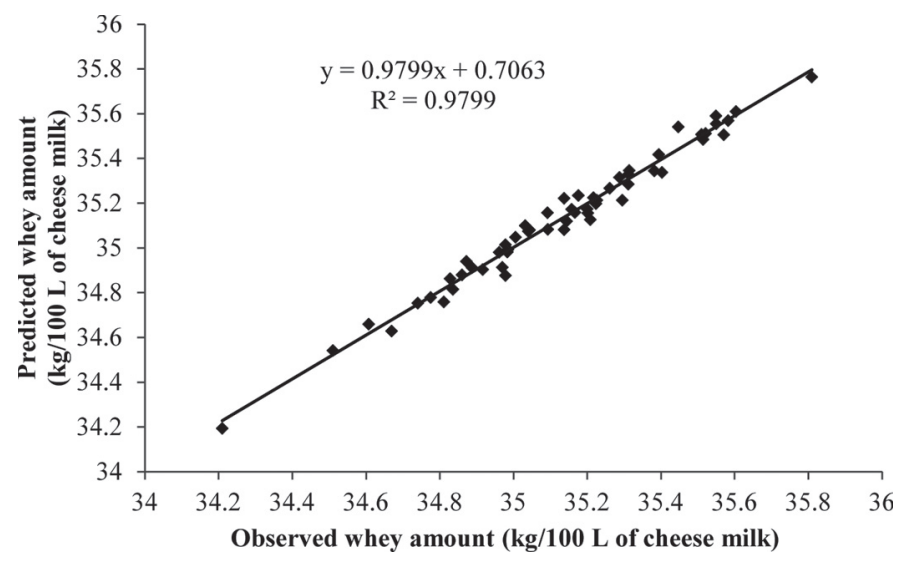

Figure 9. Calibration model established with Amaltheys (Spectralys Innovation, Romainville, France) measurements over whey amount (kg/100 L of cheese milk). 


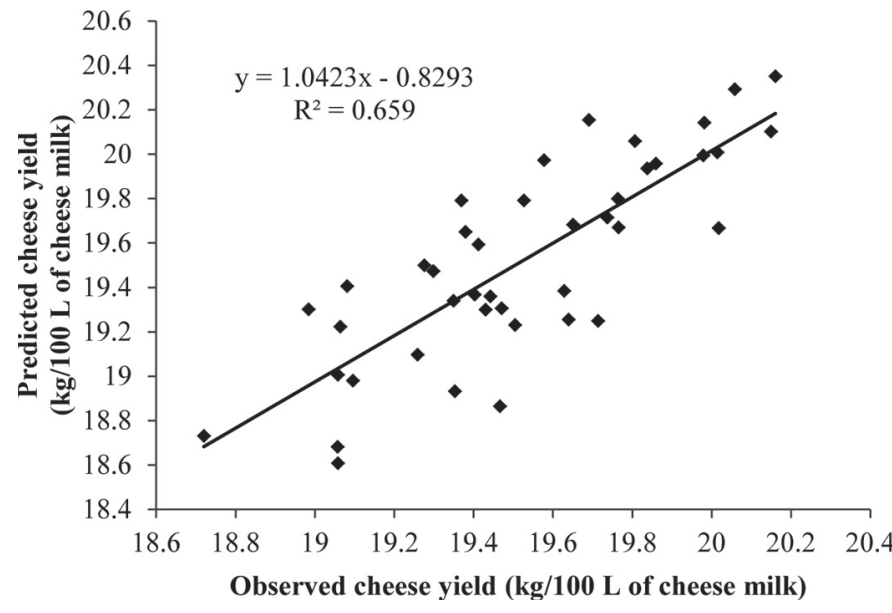

Figure 10. Calibration models established with Amaltheys (Spectralys Innovation, Romainville, France) measurements over cheese yield ( $\mathrm{kg} / 100 \mathrm{~L}$ of cheese milk).

lows applying the fast method, providing an accurate and rapid determination of sWP*. In the first part of our study, the performance criteria of Amaltheys sWP* measurement were assessed by an accredited independent laboratory: reproducibility $\left(\mathrm{S}_{\mathrm{R}}=0.100 \mathrm{~g} / \mathrm{L}\right)$, linearity $(0-7 \mathrm{~g} / \mathrm{L})$, and quantification limit $(11 \mathrm{mg} / \mathrm{L})$. Accuracy was also checked by comparison with the Kjeldahl reference method and proved to be satisfactory, with $\mathrm{S}_{\mathrm{y}, \mathrm{x}}=0.25 \mathrm{~g} / \mathrm{L}$ after minor bias corrections for the PP fraction. A slight bias was still observed between the 2 methods, owing to an approximated correction of Kjeldahl values. In the second part, we demonstrated through an industrial proof of concept that Amaltheys could be used as PAT in cheese plants. The effect of pasteurization parameters can be quantified through the milk DWP content, obtained from sWP* before and after milk treatment. Prediction of final cheese quality and yield can also be achieved at early stages of the process using calibration models. In conclusion, Amaltheys allows tight monitoring of functional products and technological quality parameters in all segments of dairy industries (cheese, yogurts, dairy powders, and so on).

\section{ACKNOWLEDGMENTS}

Authors Pierre Lacotte, Franck Gomez, Floriane Bardeau, Sabine Muller, Abdelhaq Acharid, and Ines Birlouez-Aragon declare a possible conflict of interest as employees of Spectralys Innovation when the presented work was carried out. Spectralys Innovation is a company developing and commercializing analysis tools for the food industry, among which the Amaltheys analyzer presented in this paper. However, all the experiments and results related to the method evaluation were carried out and analyzed by an independent technical center, ACTALIA Cecalait (IDF member), accredited for evaluation of analytical techniques for the dairy industry in France.

\section{REFERENCES}

Abd El-Gawad, M. A. M., and N. S. Ahmed. 2011. Cheese yield as affected by some parameters. Acta Sci. Pol. Technol. Aliment. 10:131-153.

Andrews, A. T. 1979. The formation and structure of some proteosepeptone components. J. Dairy Res. 46:215-218.

Birlouez-Aragon, I. 1997. Méthode pour caractériser le traitement thermique auquel est soumis un aliment tel qu'un lait. French Pat. No. 2,752,941.

Bonomi, F., S. Lametti, E. Pagliarini, and C. Peri. 1988. A spectrofluorimetric approach to the estimation of the surface hydrophobicity modifications in milk proteins upon thermal treatment. Milchwissenschaft 43:281-285.

Buccioni, A., S. Minier, and S. Rapaccini. 2013. Effect of total proteose-peptone content on the variability of bovine milk foaming property. Ital. J. Anim. Sci. 12:72-76.

Chiacchierini, E., F. D'Ascenzo, D. Restuccia, and G. Vinci. 2003. Milk soluble whey proteins: Fast and precise determination with Dumas method. Anal. Lett. 36:2473-2484.

Dannenberg, F. H., and G. Kessler. 1988. Reaction kinetics of the denaturation of whey proteins in milk. J. Food Sci. 53:258-263.

de Wit, J. N. 1998. Nutritional and functional characteristics of whey proteins in food products. J. Dairy Sci. 81:597-608.

Dracková, M., L. Hadra, B. Janstová, P. Navrátilová, H. Pridálová, and L. Vorlová. 2008. Analysis of goat milk by near-infrared spectroscopy. Acta Vet. Brno 77:415-422.

Dumas, J. B. A. 1831. Procédés de l'Analyse Organique. Annales de Chimie et de Physique 247:198-213.

Foegeding, E. A., J. P. Davis, D. Doucet, and M. K. McGuffey. 2002. Advances in modifying and understanding whey protein functionality. Trends Food Sci. Technol. 13:151-159.

Fox, P. F., and P. L. F. McSweeny. 2003. Advanced Dairy Chemistry Vol. 1: Proteins, Kluwer Academic/Plenum Publishers, New York, NY.

Guyomarc'h, F. 2006. Formation of heat-induced protein aggregates in milk as a means to recover the whey protein fraction in cheese manufacture, and potential of heat-treating milk at alkaline $\mathrm{pH}$ values in order to keep its rennet coagulation properties: A review. Lait 86:1-20.

Ha, E., and M. B. Zemel. 2003. Functional properties of whey, whey components, and essential amino acids: mechanisms underlying health benefits for active people. J. Nutr. Biochem. 14:251-258.

ISO. 2001. ISO8968-4:2001 (IDF 20-4: 2001). Milk-Determination of nitrogen content-Part 4: Determination of non-protein-nitrogen content. International Organization for Standardization (ISO), Geneva, Switzerland.

ISO. 2004. ISO17997-1:2004 (IDF 29-1: 2004) Milk-Determination of casein-nitrogen content-Part 1: Indirect method (Reference method). International Organization for Standardization (ISO), Geneva, Switzerland.

ISO. 2011. ISO8916-3 (FIL 128-3:2001) Lait-Définition et évaluation de la précision globale des méthodes alternatives d'analyse du lait-Partie 3: Protocole pour l'évaluation et la validation des méthodes quantitatives alternatives d'analyse du lait. International Organization for Standardization (ISO), Geneva, Switzerland.

ISO. 2014. ISO8968-1:2014 (IDF 20-1:2014) Milk and milk productsDetermination of nitrogen content-Part 1: Kjeldahl principle and crude protein calculation. International Organization for Standardization (ISO), Geneva, Switzerland.

Jankovská, R., and K. Sustová. 2003. Analysis of cow milk by near infrared spectroscopy. Czech J. Food Sci. 21:123-128. 
Jovanović, S., M. Barać, and O. Maćej. 2005. Whey proteins-Properties and possibility and application. Mljekarstvo 55:215-233.

Karamoko, G., P. Anihouvi, and C. Blecker. 2013. Evolution des connaissances sur les fonctionnalités de la fraction protéose-peptone du lait: Propriétés technofonctionnelles et biologiques. Biotechnol. Agron. Soc. Environ. 17:373-382.

Kjeldahl, J. 1883. Neue Methods zur Bestimmung des Stickstoffs in Organischen Korpern. Z. Anal. Chem. 22:366-382.

Laporte, M. F., and P. Paquin. 1999. Near infrared analysis of fat, protein and casein in cow's milk. J. Agric. Food Chem. 47:2600-2605.

Marinoni, L., L. Monti, S. Barzaghi, and B. de la Roza-Delgado. 2013. Quantification of casein fractions and of some of their genetic variants in phosphate buffer by near-infrared spectroscopy. J. Near Infrared Spectrosc. 21:385-394.

O'Callaghan, D. J. 1998. The use of on-line sensors in food processing. End of project report DPRC n²3. Dairy Products Research Centre, Moorepark, Ireland.

Pâquet, D. 1989. Revue bibliographique: La fraction protéose-peptone du lait. Lait 69:1-21.

Pâquet, D., Y. Nejjar, and G. Linden. 1988. Study of a hydrophobic protein fraction isolated from milk proteose-peptone. J. Dairy Sci. 71:1464-1471.
Pedersen, L. R. L., S. B. Nielsen, J. G. Hansted, T. E. Petersen, D. E. Otzen, and E. S. Sørensen. 2012. PP3 forms stable tetrameric structures through hydrophobic interactions via the C-terminal amphipathic helix and undergoes reversible thermal dissociation and denaturation. FEBS J. 279:336-347.

Pouliot, M., P. Paquin, R. Martel, S. F. Gauthier, and Y. Pouliot. 1997. Whey changes during processing determined by near infrared spectroscopy. J. Food Sci. 62:475-479.

Rowland, S. J. 1938. The precipitation of the proteins in milk. J. Dairy Res. 9:30-41.

Saulnier, F., F. Ferrero, A. Choukri, J. M. Girardet, and G. Linden. 1991. Estimation de la dénaturation des protéines par spectrofluorimétrie d'absorption moléculaire: Applications aux lactosérums industriels. Lait 71:511-518.

Shida, K., K. Takamizawa, M. Nagaoka, T. Kusiko, T. Osawa, and T. Tsujii. 1994. Enterotoxin-binding glycoproteins in a proteasepeptone fraction of heated bovine milk. J. Dairy Sci. 77:930-939. 